\title{
Governance as the Bane of Boko Haram Insurgency in Nigeria
}

\author{
Mohammed Mustapha, Ahmad Fauzi Abdul Hamid
}

\begin{abstract}
This article investigates into the operations of Boko Haram insurgency and its consequences on Nigeria's political and socio-economic arrangement. The paper faults the sudden development of Boko Haram on the government languorous attitude to governance. The paper is qualitative research, it relies more on the secondary form of data collection, and the theoretical thrust hinges on Ted theory of Relative Deprivation; noting that the people of Northeast feel highly deprived in the scheme of things in Nigeria. There is an acute shortage in their basic needs, high rate of unemployment, an unacceptable level of poverty and shortage of infrastructures. With the arrays of attacks, suicide bombing, abductions, armed robbery and use of Improvised Explosive Devices (IEDs), Nigeria is gradually gravitating towards a failed state. Since development cannot take place in an insecure environment, the paper recommends that there must be the full entrenchment of good governance, the military must be adequately strengthened, and poverty must be eradicated.
\end{abstract}

Key Words: Boko Haram; Insurgency; and Good Governance.

\section{INTRODUCTION}

Before the appearance of Boko Haram in Nigeria's political space, there were different sects, for instance, the Mohammed Marwa led Maitastine faction of the 1980s, the Shiite Movement under the control of Sheikh el-Zakzaky (also known as the Islamic Movement of Nigeria), the Sheikh Abubakar Gumi revolution-driven preaching from late1980s to early 1990s, and the Yobe state Taleban transformed into Boko Haram. Most of these sects (except the Shiite movement) were influenced by the Salafist ideology that form the basis of their Islamic knowledge. Abdul Hamid (2017) blamed the Salafist for the increasing radicalization of the Muslim youths. He alleges that the Salafist had expunged spirituality from Islam and emphasize the preaching of martyrdom as the ultimate prize and the only guarantee of the forgiveness of sins. This belief by many youths has increased their love for fundamentalism as against spirituality.

Boko Haram was formed based on the ideology of the Sunni sect, championing the implementation of Islamic sharia law in a heterogeneous Nigerian state. It transformed into a Salafist-jihad sect in 2009, motivated by the ideology of the Wahhabi's school of thought (Institute for Economic Peace, 2015). The benign group became violent only after

Revised Manuscript Received on September 22, 2019.

Mohammed Mustapha, Ph.D. Candidate, School of Distance Education, Universiti Sains Malaysia mohammedmustapha247@gmail.com

Prof. Dr. Ahmad Fauzi, School of Distance Education Universiti Sains Malaysia.afauzi@usm.my. the assassination of its leader Muhammad Yusuf in July 2009. The murder of Mohammed Yusuf was the genesis of the brutal phase of Boko Haram insurgency.

The Boko Haram had since then continued to unleash terror on the Nigerian state without abating. It had killed many people, destroyed houses and villages, paralyzed the economic system in the North east. Onuoha and Oyewole (2018), found that the insurgent is responsible for sending over 2.6 million people from their residents, the damages on properties worth about $\$ 9$ billion and over 100,000 lives were taken. The UNICEF also faults the insurgent for the destruction of over 1,400 schools and the death of 2,295 teachers since the crises began in 2009 (Tukur, 2017). The April 14, 2014 kidnap of over 250 female students from a Chibok school by the insurgent has gone in history to be the biggest incident so far, inducing a global crusade of "\#Bring back our Girls" (Global Terrorism Database, 2015). All these are evidence of insecurities in the country, a threat to peaceful coexistence, gravitating the nation towards a failed state and extenuation of democratic governance in Nigeria.

In this vein, therefore, to address the problems of Boko Haram, the national leadership must be well articulated and designed to bring forth purposive followership. Leadership must be reliably engaged, transparent, purposeful, visionary, integrity-driven and excellent. It must support receptiveness and responsibility; political leadership in Nigeria should see the nation's territory as a place that needs to be impacted positively for the advancement of the country (Okene, 2011). This article will be addressing mainly the following salient questions: what are the underlining factors that caused of Boko Haram? What are the consequences of the insurgent in Nigeria? How best can good governance return sanity to the Nigeran state?

\section{DEFINITION OF TERMS}

In this section of the paper, concepts that are germane to this discourse will be defined to give a comprehensive understanding of its philosophical constitution of analysis.

Governance: World Bank Report of 1994, sees governance as the way power and authority are practiced in the administration of a nation's socio-economic resources for national advancement. This definition infers that administration envelops the state's institutional and basic game plans, basic leadership procedures and usage limit, and the connection between the governing team and the governed, that is the general population as far as their way of life. To United National

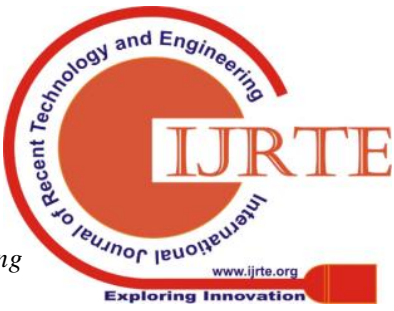




\section{Governance as The Bane of Boko Haram Insurgency in Nigeria}

Development Project (2000), good governance incorporates viable, responsive and responsible, accountable state establishments, receptiveness and integrity-driven, fighting corruption and checking illegal money laundry, equity and the supremacy of law, support for public participation in decision making, containing brutality and combating transnational wrongdoing and criminal acts.

To Okene (2011), good governance has a direct nexus with the provision of infrastructural facilities and utilities, responsibility, honesty, supremacy of law, a reduction in corruption, egalitarian economic arrangements and viable safety of human rights. This definition given by Okene is very vital for the philosophical understanding of this article whereas, good governance and advancement are essential requirements in a democratic setting if not, the nation's security will be facing more daunting problems of curbing the menace of Boko Haram.

Boko Haram: The term 'Boko Haram', meaning a group that "forbids education", in the Hausa language, "Boko" means "education or western education" while "Haram" in the Arabic language means "forbidden". The name Boko Haram is not an official name credited to the group by its founders rather it is a product of media construction that is gotten from the perception of the public on the operation of the insurgent. Onapajo and Uzodike (2012) allude that the sect was also known as Yusufiyah, meaning 'the group or followers of Yusuf' (the leader of the group), by the public. The sect's original name is Jama'atu Ahlis Suna Lidda'awati Wal Jihad (Group entrusted with the spreading of the prophetic teachings and jihad), some members of the group split and named themselves as the Wilayat al-Islamiyya Gharb Afriqiyyah (or the Islamic State of the West African Province (ISWAP) in March 2013 (Amusan and Oyewole, 2014). They believe fervently that Western effect is liable for most of the problems surrounding our political heritage, endemic corruption, underdevelopment, poverty, the dearth of infrastructures unevenness and injustices in the affected area and sees Islamic restoration as the credible alternative for national redemption.

Insurgency: Insurgency, according to Ottoh (2015) is unionized opposition group that utilizes disruption, attack and armed conflict to accomplish points. Insurgencies try to collapse the recent social order and reallocate control inside the nation. Insurgencies typically try to topple the current social order and reallocate control inside the nation.

\section{BRIEF HISTORY AND IDEOLOGY OF BOKO HARAM INSURGENCY}

Boko Haram is a Salafist Islamic movement highly influenced by the literature of ibn Taymiyyah and is found in north-eastern Nigeria. It is believed that Boko Haram started its activities in Maiduguri, Borno State and is greatly limited in the north eastern states of Borno, Yobe, and Adamawa, from where it spread to virtually all regions of northern Nigeria and advancing towards other parts of the country (US House Committee on Homeland Security, 2013: 7). Nevertheless, it is widely accepted among the local Hausa population that Boko Haram connotes "Western education is forbidden".

There's controversy surrounding the real date of Boko Haram appearance in Nigeria. However, there are contradicting documentation on the actual year of formation of Boko Haram there is the belief that the sect launched 1995 under the tutelage of Abubakar Lawan (Ujah, 2009). Other authors and investigators agreed that it started in 2002 with few frustrated students of University of Maiduguri going to meet Mohammed Yusuf expressing their disapproval to western education and civilization, which marked the beginning of the formation of the Boko Haram sect with an initial intention of mentoring and evangelism (Umar, 2009; Farouk, 2015). What is however known presently as Boko Haram has not to change into the guerrilla bunch it is today until Yusuf assumed leadership of the group. From early 2000 under Yusuf, the sect developed radical views about Islam that rejected westernization and modernization.

Boko Haram had a shadowy goal of establishing Shariah law originally in Borno and subsequently Nigeria and beyond. Its ideologue and creator, Muhammad Yusuf born in 1970 and acquired some knowledge in Qur'anic exegesis, Arabic and hadith. He was a charismatic leader of the group and a highly respected personality among its peers. Yusuf preached radical and provocative sermons against moderate Islamic clerics, and political institutions. The group rejected all forms of western culture and influence and sought the enactment of Sharia law within all over the country. The group recruits its members among the poorest, unemployed, criminals, drug addicts, as well as the educated and the employed. They called themselves the "Nigerian Taleban" and adopted a modest way of life in rural parts of the northeast, which the group named "Afghanistan" (Sani, 2011).

In 2002, Boko Haram was started as a non-militant, and its operations were limited to Borno, Yobe and Bauchi. Yusuf and his group showed severe hatred for western education and civilization; this was predicated in their philosophical underpinning. He also saw the state as a product of westernization because of its ideas and working system. Along these lines, he and his supporters separated themselves from the state and blatantly defied established the state's laws. Yusuf kept up the conviction which he and his supporters 'will preferably die than to surrender to the corrupt system in the nation'. (Sani, 2011). It was Yusuf disapproval of westernization that led to his conclusion that democracy is kufr (disbelieve). It is against this background the sect had many conflicts with the security agents before the July 2009 event that brought Boko Haram into the spotlight.

The killing of Mohammed Yusuf was a watershed in the development of the insurgent's revolt in Nigeria. Some of their members went into hiding after the face-off that led to the death Yusuf ended in 2009, they re-emerged in 2010 under the control of Abubakar Shekau as a fierce and violent sect resolved to retaliate for the death of its leader. In 2010, the sect organized several violent assaults against 
government institutions in many northern states. Under Shekau's leadership, the Boko Haram became brutal and waged deadly attacks that mostly targeted common citizens through killings, assaults, bombings, armed robbery, looting, abductions, invasion of border communities, and seizures and control of territory in Nigeria. Shekau transformed the group into most dangerous terrorist in African history (Oftedal, 2013).

\section{THEORETICAL FRAMEWORK AND METHODOLOGY}

To begin with, there are several theories on violent conflicts inclusive of communal unrest that might help explain the basic question of Boko Haram insurgency in Nigeria. This study's argument will be tailored towards the theory of Relative Deprivation of Ted Robert Gurr. Gurr in his work titled "Why Men Rebel", published in 1970, contends that individuals ended up disappointed if they believe they have less of what they ought to and could have. After some time, such disappointment prompts dissatisfaction and then resistance against the perceived or real oppressors and their source of deprivation. Economic deprivation and endemic poverty are negative triggers for violent political movement and terrorism in any country. In the same vein, Rummel (1977) concludes that a consequence of frustration is always aggression. This assertion was supported by the work of Davies (1962) when he wrote that political violence becomes unavoidable if there is an unjustifiable gap between what the masses need and what they have; this variance according to him is a frustrating and annoying experience that could result in either rebellion or revolution.

In relating the theory to this paper, the acts of insurgency as perpetuated by many groups is caused by long years of neglect and deprivation. Besides Boko Haram, there are other groups that have agitated violently against the state., For example, the Niger-Delta militants, Movement for the Emancipation of Niger Delta (MEND), Oodua People's Congress (OPC), Mobilization for the Actualization of Sovereign State of Biafra (MASSOB) amongst others. Reasons adduced for their militancy include the increasing rate of unemployment, abject poverty, the dearth of infrastructure, marginalization and bad governance. And when there is no correlation between what the people need and what they get, it can easily lead to frustration and a very negative reaction.

It is evident from the previous that the level of poverty in Northeast is deep-rooted; it calls for a closer look than what it presently got. Sectors like agriculture, textiles, and manufacturing industries were the mainstay of the economy of northern Nigeria, and it has been neglected by successive governments since independence. This abdication of responsibility could be attributed to the level of unemployment and the raging hunger in the area. Unemployment in some northern states is estimated at above $80 \%$, and indicators in health and education are among the lowest in the country (Akinola, 2015). Distinctions in the standard of living is as well a determinant factor in thein the apparent feeling of hardship among the people. So, it is easy to conclude that such lack or deprivations play a paramount part in the development of the insurgent group.

The methodology for this study is anchored on secondary data literature, magazines, journals, television documentaries, internet materials etc. The need for the adoption of secondary sources of data is as a result of the dangerous nature of the sect and the Northeast region. The area is not safe for on-the-field research work, questionnaire administrations and interview session in all the regions are practically not safe because the people are so sceptical, they don't know who to trust or believe. So, this paper is qualitative research.

\section{CAUSES OF BOKO HARAM INSURGENCY IN NIGERIA}

Lots of reasons are adduced as the reasons of Boko Haram insurgency, and most of these reasons could have been averted with effective governance. Some of the reasons are caused by citizens who feel alienated from the benefits or dividend of democracy. The reasons can best be categorized into three, that is political causes, socio-economic causes and ethnoreligious causes of the insurgency

\section{A. Political Perspective}

The leading causes of insurgencies everywhere could be attributed to the lack of political will from the government from the beginning. Eubank and Weinberg (2001) opined that regarding the main political drivers of insurgency, a few investigations have shown that the absence of common freedoms, corruption, feeble political organizations, unstable political system, weak state, high level of subjugation, ethno-religious conflicts can instigate the frequency of terrorism.

Furthermore, an investigation by Piazza (2006) demonstrates that countries with substantial complex multiparty system are more inclined to frequent cases of insurgencies than those with a couple of homogeneous systems. Also, countries practicing democracy as a system of government are thought to be in a more favored position to thwart insurgency bombardments; they are more inclined to assaults compared to countries with the oligarchic government. The principle and ideals of democracy make it easy for insurgency or terrorism to flourish; principles like respect for national identity or symbols, freedom of association, free press and fundamental human rights amongst others, given clearance for the insurgents to hide and perpetuate their evil.

On internal terrorism in the Northeast, some investigations faulted the development of Boko Haram on the nation's political system. Botha, Ewi, Salifu and Abdile (2017) contend that Boko Haram is a product of politics, supported by politicians. As indicated by Mbah, Nwangwu and Edeh (2017) Boko Haram rose up out of the battle between the political elites of both the north and southern counterpart on who controls power at the federal level,

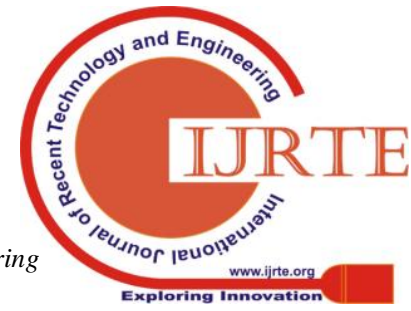




\section{Governance as The Bane of Boko Haram Insurgency in Nigeria}

particularly after the demise of President Umar Yar'Adua. The victory of Jonathan Goodluck in 2011 at that point prompted the utilization of Boko Haram as a tool to weaken his government by the elites of northern extraction (Okoro, 2014). Mbah et al. contend that these cases cannot completely clarify the rise of the sect since there are other factors that facilitated the growth of the sect. For example, in their research, they contend that development of the sect could be connected to poor governance, deep-rooted corruption and economic marginalization in the zone, which has aided the growth of the radical groups.

\section{B. Socio-Economic Perspective:}

Poverty and joblessness have been recognized as primary reasons for terrorism. In any case, research carried out by Krueger and Maleckova (2003) discovered no connection between poverty, joblessness and terrorism. The general conviction of the security and intelligence experts is that individuals whose basic needs are denied are bound to fall back on violence as an approach to express their complaints. That is poverty and joblessness breeds insurgency. The hypothesis of relative deprivation as the theoretical framework of this study clarifies that when individuals feel denied of something they are hoping to have, they end up being discontented, thus could utilize brutality to express their grievances. Bhatia and Ghanem (2017) in their research analyzed the connection between education, joblessness also, fierce fanaticism, be that as it may, found that jobless instructed youth are bound to be radicalized by the militant group because of the joblessness and absence of business opportunities in Arab countries. Ayegba (2015) contends that poverty and joblessness are the main triggers behind the rebellion in Nigeria. Moreover, he argued that the level of youth joblessness has brought about destitution and anxiety in the nation.

David, Asuelime and Onapajo (2016) argue that social and economic indices such as destitution, joblessness, unevenness, underdevelopment, illiteracy, inter alia, underline the appearance and consistency of Boko Haram insurgency. These affirmations recommend that the endemic destitution and joblessness in the north make the circumstance for the vulnerable youths to be controlled and enlisted by the group. While some argued that there is no connection between poverty and insurgency, however, the cyclic vicious of poverty and joblessness supported the people to be vulnerable for Boko Haram enlistment. Botha and Abdile (2014) confirm that, due to adverse economic conditions and unemployment in Somalia, some people viewed al-Shabaab as a potential employer. So many unemployed youths, illiterates and poor people feel not catered for by the government and became encouraged to associate with Boko Haram as they are jobless and see insurgency as a vocation or for the little remuneration given as motivation.

\section{Ethno-Religious Perspective}

Religious extremism is another known factor that can cause terrorism in a country. Religion assumed a crucial stance in the operations of Boko Haram. They hold a belief system that is used to legitimize their egregious wrongdoings. For instance, the group plans to impose Sharia law and establish an Islamic state in Northern Nigeria. Accordingly, it has battled against any group or western idea, which they perceive is against their Islam ideology. This has led to the idea that terrorism is connected to religious fundamentalism (John and Asch, 2018). In the article authored by Onuoha and titled Why do people join Boko Haram? He opined that illiteracy and lack of knowledge are the main factors prompting the acceptance of fanatical spiritual ideology, particularly among the youths (Onuoha, 2014).

More so, religious and ethnic tensions are found to cause terrorism. Nigeria has encountered myriads of ethno-religious conflicts (Haldun and Odukoya, 2016). Although it is unfair to conclude that the rise of Boko Haram relates to religious or ethnic violence, though, Adelaja, Labo and Pena (2018) in their study discovered a positive connection between religious and ethnic pressures and terrorism. This means that a religiously tensed society is a conducive place for breeding terrorism and insurgency.

\section{CONSEQUENCES OF BOKO HARAM INSURGENCY IN NIGERIA}

The consequences of Boko Haram have affected not just the northeast region but Nigeria as a nation and some of her neighboring countries. Lots of factors have been credited for causing Boko Haram crises and the apparent assistance gotten from their immediate environment. Some of these factors include endemic poverty and low development level of the North compared to the more developed South; pervasive corruption in the government and high handedness and oppressive behavior meted on the local population by the military forces. The sect also believes that Nigeria's relationship with the western countries is a contributing factor responsible for many of the problems in Nigeria and failure of governance. There is a high level of poverty in the North, and many of the residents are staying in abject poverty (Odobo, 2017). Some of the consequences will be discussed briefly:

\section{A. Socio-Political Consequences}

The government has a responsibility of protecting the lives and properties of its citizens. And any government who fails to safeguard the lives and properties of its citizens is invariably deteriorating into a failed government. The various attacks from the Boko Haram insurgents is a direct affront on the sovereignty of Nigeria. The group took over the control of some local government areas in the Northeast zones of the country and mount their flag in those areas before 2015. The insurgency of Boko Haram in Nigeria has reduced drastically the efficacy of government in the affected territory. Although, Nigerian government officials are used to making good promises to gain individuals' support; in my perspective, the former President Jonathan and

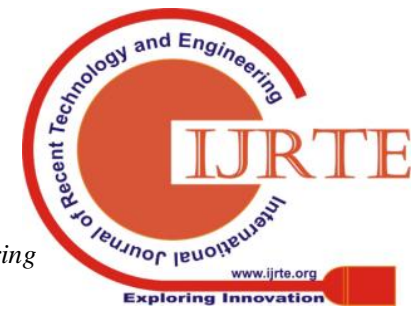


President Buhari were not having the capacity to satisfy the bigger parts of their promises because of the crises caused in the Nation by the insurgency of Boko Haram.

The uprising of Boko Haram in Nigeria has casted a negative impression on her and dent her relationship with other Nation of the world because of bombing, abduction and hostage taking with or without request for ransom; especially of foreigners which have resulted in the death of some of them and have much disturbed the International Community. It could be recalled that a couple of years back, United State of America advised her nationals not to visit certain states in Nigeria, not also forgetting that United Nation has once included Nigeria in the list of the terrorist nation in the World which was later removed (Odidison and Johnson, 2012).

The social challenges exhibited by the uprising of the insurgent can similarly be seen by the migration of many residents who are from various parts of the nation; out of the affected zone of the country, especially Maiduguri, a major in Borno State.

\section{B. Security Consequence}

The uprising of Boko Haram has presented genuine security difficulties to Nigeria, as in individuals are been prevented from exercising their fundamental rights in the society and denying them the usual opportunity of contributing to the nation's development because of fear of assault from members of the insurgents. Especially in some areas of Northern Nigeria where Boko Haram has assumed control through suicide bombers and launching of violent assaults on innocuous people which experience have shown that the assault is not from Boko Haram alone, but some dissidents have been capitalizing on the presence of Boko Haram to nurture their personal and ethnical motives by attacking other people.

\section{Economic consequences}

The four states of Adamawa, Borno, Bauchi and Yobe are the crux of insurgency in the northeast. Thousands of inhabitants have been killed, economic activities paralysed in the bloody campaign of Boko Haram. Aro (2013) notice that Boko Haram have not just prompted closure and/or forfeiture of people's business activities within the Northeast, but it has provoked the migration of individuals from the area. It has prompted a decline in businesses and supplies from North owing to hearsay that Boko Haram members are planning to send poisoned food items from their zones to other states. The largest market in Maiduguri city was severely affected that a large portion of the shops in the market was shut as the owners have fled the state in search of safety.

Boko Haram extremists expanded the expenses of running commercial activities by the private sector as well as the provision public utilities to the populace since assets that would have been committed to boosting output, finance education and training, health and other well-being programs are diverted into fighting insurgency and prevention as well as purchasing of arms and ammunition to fight insurgency. Nigeria's former Finance Minister, Dr.
Ngozi Okonjo-Iweala, made an analysis of the 2013 budget, she said over N950 billion was budgeted for national security purposes, comprised of N320 billion for the Police, N364 billion for the Armed Forces, N115 billion for the Office of the NSA, and N154 billion for the Ministry of the Interior (Imaji, Ranjit Singh and Muhammad, 2015). This amount is twice the amount allocated to education and health, which is counter-productive to national development. The improvement of general public to a great extent relies upon the level of crime. If the level of crime in any society is high, it will invariably scare or discourage investors from doing business in the country (Adebayo, 2013).

\section{The National Unity challenges}

One of the biggest challenges of Nigeria before the advent of Boko Haram is how to make a truly united Nigeria. Nigeria, as a Nation, is a plural state with over 300 ethnic groups, different religious bodies and diverse cultural heritage. Political and economic policies of the state always interpreted along with ethno-religious sentiments. The coming of Boko Haram into the limelight in 2009 has further strained the unity of the country. At the early stage of the insurgents, most of the attacks, according to Aro (2013), were targeted at non-Northerners. It is noteworthy Nigeria's unity has always been shaky before the advent of Boko Haram, that has given political coloration to its activities because of the operations of Boko Haram which has instigated other regions to continue their clamoring for secession.

\section{IMPORT OF GOOD GOVERNANCE}

The fight against Boko Haram insurgency demands strong and effective governance to make out success. There is need to elect/appoint a leader that will move beyond the rhetoric's of fighting insurgents; a leader that will interpret bold vision into action as expected in the election of President Muhammadu Buhari in 2015. The little success recorded so far, as a result, a clear intention and much is still needed in the aspect of good governance. The expectations include the following:

\section{A. Strengthening the Military}

The Boko Haram insurgent is a national threat, and it needs to be treated as such. The Nigeria military needs total transformation and overhaul of its hardware. The military hardware before Boko Haram came to limelight can no longer be trusted in the face of the internationalization of the group, it must take an aggressive force to decimate any threat to the nation's sovereignty. There is the need to synergize the Airforce, the Army, the Navy, the Police and the local vigilantes. The strong base of the group can be attacked from aerial by the Nigerian Airforce while the others take charge of the ground battles. To get the best out of the military, there is the need for professional retraining, especially in the face of the asymmetric tactics adopted by the insurgents. The military in Nigeria was not adequately schooled in guerrilla battle, and the need

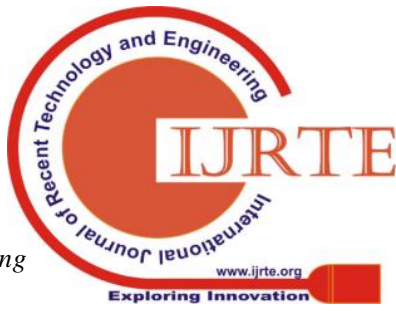




\section{Governance as The Bane of Boko Haram Insurgency in Nigeria}

for constant retraining is a prerequisite for victory.

\section{B. Increase Budgetary Allocations of the Military}

The safety of lives and properties of the people is the primary duty of any responsible government and therefore, those saddled with the responsibility of fighting the insurgency must be adequately taken care of. There are cases of complaints of neglect and non-payment of allowances to the military contingents in the Northeast, which is not good, and it is highly demoralizing (Afeikhena, 2015). The allocation should be made direct to the people at the battlefield to avoid misappropriations and embezzling by the superior officers in office. Those on the field should naturally attract more incentives than the others.

\section{Encourage dialogue in the fight against insurgence}

There are no absolute military answers to pulling a country or zone out of violent fanaticism and insurgency. As experiences have shown from other countries, there is a need to desert the traditional military-driven approach as the unparalleled choice for engaging in asymmetric warfare. While not disregarding the significance of utilizing military option which is the "hard power approach", the government should also adopt the "soft power approach", that is engaged in dialogue and improve on intelligence gathering. The adoption of both approaches will about smart result in the fight against insurgences.

\section{Policies of Poverty Alleviations}

The root causes of Boko Haram include poverty, and the government should enact and implement policies aimed at alleviating poverty in Nigeria, especially in the Northeast. The acute shortage of basic needs has led to lots of deprivations, the dearth of infrastructural facilities and the inability of the populace to attend their choice school because of the level of poverty of most of the people of Northern Nigeria.

\section{E. Creating Job Opportunities for The People}

In any state where most able-bodied men are not employed, and conducive atmosphere is not created for people to engage themselves productively, such is a recipe for insecurity, and the people are vulnerable for the recruitment for Boko Haram. So, it is the responsibility of the government to create employment or create a conducive environment for private investments and establishment.

\section{F. Streamline the Preaching in Every Religious Centre}

Christian and Muslim adherents need to stay away from fanaticism in their various religious practice, and both religious leaders (Christians and Muslims) should ensure this during their lectures and sermons. They should avoid provocative preaching and teach perseverance and tolerance. The government can as well regulate the sermons by establishing a ministry saddle with the responsibilities of regulating sermons and registrations of churches and mosques.

\section{CONCLUSION}

Boko Haram insurgency appears to be the greatest challenge Nigeria has faced since her independence in 1960. The insurgents have masterminded series of attacks in Nigeria, killing tens of thousands and destroying properties that worth billions of dollars over the years. It could be recalled that the main causes of this insurgence are centred on deprivations, social injustice, neglect, an unacceptable level of poverty and marginalization. For the government to decimate the Boko Haram insurgents, there is the need to entrench good and effective governance that will be built on the principle of the rule of law, transparency and accountability. With these, the dearth of infrastructures will be addressed, and the basic needs of the people will alleviate the poverty level and forestall the emergence of another group in the future, after this dreaded Boko Haram has been decimated.

\section{REFERENCES}

[1] AbdulHamid, Ahmad Fauzi (2017). IS beliefs devoid of spirituality, https://freemalaysiatoday.com/category/nation,2017/08/30/is-beliefs-de void-of-spirituality

[2] Abdullahi, D. (2012). Good governance as panacea to the socio-economic crises in Nigeria. Journal of Business and Management (IOSRJBM), 2(3), $36-40$.

[3] Adelaja, A; Labo, A. \& Penar, E. (2018). Public Opinion on the Roo Causes of Terrorism and Objectives of Terrorists: A Boko Haram Case Study. Perspectives of terrorism, 12(3) $35-49$.

[4] Adebayo, A.A. (2013). Youths' Unemployment and crime in Nigeria: A nexus and implications for national development. International Journal of Sociology and Anthropology, 5(8), 350-357.

[5] Afeikhena, J. (2015). Lessons from Colombia for curbing the Boko Haram insurgency in Nigeria. Prism 5(2), 95 - 105.

[6] Akinola, O. (2015). Boko Haram insurgency in Nigeria: Between Islamic fundamentalism, politics, and poverty. African Security 8 (1) 11 -12 .

[7] Amusan, L. \& Oyewole, S (2014). Boko Haram terrorism in Nigeria: A Reflection on the Failure of Democratic Containment. Politeia, 33(1), 35-59.

[8] Aro, I. O. (2013). Boko Haram insurgency in Nigeria: Its implications and way forward towards avoidance of future insurgency. International Journal of Scientific and Research Publications, 3 (11), 1 - 8.

[9] Avwode, A. (2009). Boko Haram: former commissioner among sect members killed, The Nation, 1 August.

[10] Ayegba, U. S. (2015). Unemployment and poverty as sources and consequence of insecurity in Nigeria: The Boko Haram insurgency revisited. African Journal of Political Science and International Relations 9 (3) $96-98$

[11] Bhatia, K. \& Ghanem, H. (2017). How do education and unemployment affect support for violent extremism: Evidence from eight Arab countries. Brooking Institutes Global and Economic Development (Working paper 102), $9-10$.

[12] Botha, A. \& Abdile, M. (2014). Radicalization and al-Shabaah recruitment in Somalia. Institute for Security Studies Paper 266, 8.

[13] Botha, A.; Ewi, M; Salifu, U. \& Abdile, M. (2017). Understanding Nigeria citizens' perspectives on Boko Haram. Institute for Security Studies Monograph. 196, 29.

[14] Boye, R. R. (2013). Nigeria Anti-Terrorism law and global security. Africa-Dynamics of Social Science Research 4(1) 56 -64.

[15] David, O. J.; Asuelime, L. E. \& Onapajo, H. (2015). Boko Haram: The socio-economic drivers. Switzerland: Springer, 83 -99.

[16] Davies, J. (1962). Towards a theory of revolution. American Sociological Review, 27(1), 5-19.

[17] Eubank, W \& Weinberg, L. (2001). Terrorism and Democracy Perpetrators: and Victims. Terrorism and Political Violence 13(1) 155-164. 
[18] Farouk, C. (2015). Who are Nigeri's Boko Haram Islamists? BBC Africa. Retrieved

from http://www.bbc.com/news/world-africa-13809501

[19] Global Terrorism Database (2015). 1970-2015. Available at http://www.start.umd.edu/gtd

[20] Gurr, T. R. (1970). Why men rebel. Princeton, NJ: Center of International Studies, Princeton University Press.

[21] Haldun, C. \& Odukoya, O. A. (2016). Ethnic and religious crises in Nigeria: A specific analysis upon identities (1999- 2013)." African Center for the Constructive Resolution of Dispute. http://www.accord.org.za/ajcr-issues/ethnic-religiouscrises-nigeria/

[22] Idris, H. \& Ibrahim, Y. (2011). Boko Haram widows, orphans abandoned in pains, Sunday Trust, 23 January.

[23] Imaji, Z.O.S., Ranjit Singh, D.S. \& Muhammad F.O. (2015) Governance and Boko Haram Insurgence in Nigeria: An analysis. Academic Journal of Interdisciplinary Studies. 4(2), 35-44.

[24] Institute for Economics and Peace, (2015). Global Terrorism Index. New York: IEP.

[25] John, C. \& Asch, H. (2018). Boko Haram and Nigeria's pervasive violence,https://www.cfr.org/expert-brief/bokoharam-and-Nigeria's-per vasive-violence, accessed October 20

[26] Krueger, A. B. \& Maleckova, J. (2003). Education, poverty and terrorism: Is there a causal connection. Journal of Economic Perspectives 17 (4), 121 - 133

[27] Mbah, P; Nwangwu, C. \& Edeh, H. C. (2017). Elite politics and the emergence of Boko Haram insurgency in Nigeria. Trames, 21 (2), 177 -178 .

[28] Obamwonyi, S.E \& Owenvbuigie, R. O. (2015). Boko Haram Insurgency in Nigeria: A Nation-State in Search of Cohesion for National Development. International Journal of Arts and Humanities, 4(1), 31 45 .

[29] Odidison, O. \& Johnson B. (2012). Boko Haram funding: Nigeria may face International Sanctions, http://www.nncpo.netindex.phpoption=com_content\&view=article \&id= 832boko-haram-funding-nigeria-may-face-international-sanctions-\&ca (24th August 2015)

[30] Odobo, S. O. (2017). Boko Haram Internationalism and its Sub-Regional Security Implications. African Journal of Governance and Development. 6(2), 11 -37

[31] Oftedal, E. (2013). Boko Haram - An Overview, Forsvarets forsknings institutt, Norwegian

[32] Okene, A. A. (2011). National security, good governance and integration in Nigeria since 1999: Discourse. Asia Social Science, 7(10), 166 - 176.

[33] Okoro, E. R. (2014) Terrorism and governance crisis: The Boko Haram experience in Nigeria. African Journal on Conflict Resolution. 14 (2), $121-122$.

[34] Onuoha, F (2014). Why the youth join Boko Haram? United State Institute of Peace Special Report, 348, 5.

[35] Ottoh, F. O. (2015). Changing the pattern of warfare in Africa: Boko Haram Insurgency in Nigeria. Conflict Studies Quarterly. Special Issue, 23-40

[36] Piazza, A.J. (2006). Rooted in Poverty: Terrorism, Poor Economic Development, and Social Cleavages. Terrorism and Political Violence 18 (1), $169-170$

[37] Rummel, R.J. (1977). Frustration, deprivation, aggression, and the conflict helix. In R.J Rummel. Understanding conflict and war: Conflict in Perspective, 3. California: Sage publications. Retrieved from https://www.hawaii.edu/powerkills/note12.html

[38] Sani, S. (2011). "Boko Haram: History, ideas, and revolt", Vanguard, July 7 , Available at: http://www.vanguardngr.com/2011/07/boko-haram-history-ideas-andre volt-5/.

[39] Tukur, S. (2017). Shocking Revelation: 100,000 killed, two million displaced by Boko Haram Insurgency, Borno Governor Says," Premium Times, February 13

[40] Ujah, E. (2009). Yaradua orders probe of Boko Haram's leaders' killing, Vanguard, 4 August 2009, http://www.vanguardngr.com/2009/08/yaradua-orders-probe-of-boko-h aram-leaders-killing/ accessed 30 March 2018.

[41] Umar, G. I. (2009). Boko Haram: how it all began, Daily Trust, 2 August.

[42] US House Committee on Homeland Security 2013. "Boko Haram, Growing Threat to the U.S. Homeland". Available at: https://homeland.house.gov/boko-haram-growingthreat- us-homeland/ Accessed December 22, 2016.

43] Uzodike, N. O. \& Onapajo, H. (2012). Boko Haram terrorism in Nigeria Man, the state, and the international system. in African Security Review 21(3),24-39.

[44] The World Bank, (1989). Governance - The World Bank's Experience, A World Bank Publication, Washington D.C., p. 66 available online at: http://documents.worldbank.org/curated/en /711471468765285964/pdf/multi0page.pdf last accessed on October 5 th, 2018.

\section{AUTHORS PROFILE}

I am Mohammed Mustapha, and I am Ph.D. Candidate,and affiliated with School of Distance Education, Universiti Sains Malaysia. My area of interest is governance. mohammedmustapha247@gmail.com.

My name is Prof. Dr. Ahmad Fauzi, and currently working with School of Distance Education Universiti Sains Malaysia.

My area of interest is governance. For detail contact me at: afauzi@usm.my 